\title{
BERITA BOHONG (HOAKS) PADA MEDIA SOSIAL DALAM PERSPEKTIF PERUNDANG-UNDANGAN DI INDONESIA
}

\author{
Anny susilowati ${ }^{1}$ \\ Yahya ahmad zein ${ }^{2}$ \\ Nurasikin $^{3}$ \\ Universitas Borneo Tarakan
}

\begin{abstract}
This research is motivated by the rise of hoaxes every time before the Presidential Election (Pilpres) in Indonesia. Later hoaxes are increasingly massive and have entered all lines of life, so it is very difficult to determine which news is good and where lies. For this reason, it is necessary to clarify the formulation of juridical regulations, regarding hoax aspects that can be held accountable.This research then sets two goals, namely: First, to analyze and explain a number of laws and regulations relating to hoaxes; Second, to analyze and explain the hoax criteria contained in social media.This research method uses a type of normative legal research, with three approaches as the basis of its analysis, namely: Approach to legislation, namely to conduct an analysis of legislation about hoaxes, with a review of relevant product laws.

Conceptual approach, through this approach, researchers study views and doctrines in law, then find ideas that give birth to legal notions, legal concepts and legal principles relevant to hoaxes. As well as the case approach, namely by examining cases relating to the issues faced which have become court decisions and have permanent legal force.The results showed that hoax qualifications that could be liable by referring to Law Number 1 Year 1946 concerning Criminal Law Regulations, Article 14 and 15 and Law Number 19 Year 2016 concerning amendments to Law Number 11 Year 2008 concerning Electronic Information and Transactions (ITE) article 28 paragraph (1). In Law No. 1 of 1946 the perpetrators can be charged if they have fulfilled the element intentionally or have the intention to cause trouble and the person must at least have the presumption that the news is false news.

Whereas in Act No. 19 of 2016 the culprit can be snared if everyone intentionally means that they have bad intentions and without the right to spread false and misleading news, which means making other people astray which results in consumer losses in electronic transactions. Deliberately, making a misguided and making consumer losses is a requirement that must be fulfilled. So that in article $45 \mathrm{~A}$ paragraph 1, the
\end{abstract}

\footnotetext{
1 Journalist Radar Tarakan, Mahasiswa Magister Hukum Universitas Borneo Tarakan, https://id.linkedin.com/in/anny-susilowati-999789122

2 Dosen Fakultas Hukum Universitas Borneo Tarakan

${ }^{3}$ Dosen Fakultas Hukum Universitas Borneo Tarakan
} 
culprit can be sentenced to six years imprisonment and a fine of Rp1 billion.Researcher's recommendation, It is recommended that the action qualifications spread hoaxes on social media that accountability can be requested in a more specific law, namely social media law. This is to anticipate the development of social media going forward.

Keywords: News, Hoax News, Social Media, and ITE Law

\section{A. Pendahuluan}

Di era digital data dan informasi ibarat air bah. Meluncur deras dari berbagai sumber. Banyak sekali data dan informasi bertebaran dan masyarakat sulit memilah, mana data dan informasi yang benar-benar akurat, kredibel dan bisa dipercaya dan mana data dan informasi yang tidak benar.

Besarnya kebutuhan masyarakat akan data dan informasi membuat jumlah pengguna internet dan telepon seluler di Indonesia terus berkembang. Pengguna internet di Indonesia dari hasil survei Asosiasi Penyelenggara Jasa Internet Indonesia (APJII) 2017 sebesar 143,26 juta atau 54,68 persen dari total penduduk 262 juta orang. Data ini naik dari tahun sebelumnya 132,7 juta jiwa pengguna internet. ${ }^{4}$

APJII juga mencatat perkembangan pengguna internet di Indonesia yang sangat cepat dalam 20 tahunan terakhir. Semula jumlahnya hanya 0,5 juta tahun 1998, kemudian melejit menjadi 4,2 juta di tahun 2001. Selanjutnya bisa ditebak makin banyak pengguna internet seiring dengan kebutuhan dalam berbagai bidang. Dalam sepuluh tahun terakhir saja tercatat 20 juta pengguna tahun 2007, tiga tahun berikutnya menjadi 42 juta. Berarti dua kali lipat lebih kenaikannya. Tahun 2013 jumlah pengguna internet 82 juta, tahun-tahun berikutnya menjadi 88,1 juta tahun 2014, 110,2 juta pada tahun 2015 dan 132,7 juta pada tahun 2016.

Hoaks tak terlepas dari perkembangan media sosial yang mengantarkannya. Semula berkembang dalam tatanan masyarakat sosial yang sederhana dan masih sangat tradisional. Lama kelamaan seiring dengan kemajuan zaman dan cara berkomunikasi yang terus mengalami evolusi, hoaks pun seolah memiliki tempatnya di media sosial. Budaya saling berbagi kabar, bercerita, saling sapa, terus berkembang.

\footnotetext{
${ }^{4}$ https://www.apjii.or.id/content/read/39/342/Hasil-Survei-Penetrasi-dan-Perilaku Pengguna Internet-Indonesia-2017. Diunduh tanggal 6 april 2019 pukul 10.05 wita.
} 
Seiring waktu berjalan, media sosial pun turut berevolusi. Sejak ditemukannya mesin telegraf 1792, telepon 1890, radio 1891, email 1966, instant messenger chat 1997, blogger 1999, wikipedia 2001, friendster dan linkedin 2002. Tahun 2002 itulah mulai semarak muncul media-media sosial yang menjadikan warga suatu negara merasa dekat dengan warga di belahan bumi lainnya. Selain friendster dan linkedin, adapula meetup, RSS dan technorati. Tahun 2003, berlanjut kemunculan facebook yang kemudian mengakuisisi skype dan wordpress, lalu my space, second life dan xing. Flicker dan digg muncul tahun 2004.

Perkembangan selanjutnya adalah situs berbagi video youtube telah lahir tahun 2005, selain itu ada bebo, reddit dan ning. Tahun 2006 muncul twitter atau aplikasi berbagi pesan singkat, sportify atau aplikasi berbagi lagu, dan slideshare situs berbagi slide. Kebutuhan berkomunikasi terus berkembang, media baru bernama Whatsapp muncul tahun 2009, tahun 2011 muncul pinterest yang membagikan foto-foto dan desain grafis. Semarak media sosial membuat Google+ atau dinamakan Google plus yang menghubungkan antar anggotanya. Teknologi komputer baik perangkat keras (hardware) dan perangkat lunak (software), jaringan komunikasi dan teknologi multimedia dimungkinkan menjadi tulang punggung masyarakat abad 21. Namun demikian, selain keuntungan yang menjanjikan dari teknologi informasi, teknologi internet ternyata memunculkan permasalahan baru dalam tatanan kehidupan bermasyarakat, misalnya pelanggaran hak kekayaan intelektual; penipuan dalam transaksi elektronik; perpajakan dalam perdagangan elektronik; dan cybercrime. ${ }^{5}$

Seiring dengan perkembangan dunia informasi, memberikan kita berbagai kemudahan untuk dengan cepat mendapatkan berbagai kabar berita terbaru dari seluruh dunia. Tak hanya untuk mendapatkan berbagai informasi atau berita, dunia internet dan media sosial juga dapat kita gunakan untuk berbagi informasi dan menyebarluaskan berbagai berita keseluruh dunia dengan sangat cepat. ${ }^{6}$ Bahkan berita bohong (hoaks) atau informasi palsu pun yang tersebar dengan sangat cepat di dunia internet dan media

\footnotetext{
5 Danrivanto Budhijanto, Revolusi Cyberlaw Indonesia Pembaruan dan Revisi UU ITE 2016, Refika Aditama, Bandung, 2017, h. 3
}

${ }^{6}$ Nudirman Munir, Pengantar hukum siber Indonesia, Raja Grafindo Persada, Depok, 2019, h.25 
sosial tersebut berisikan tentang hal-hal besar yang menggemparkan dunia, berisi tentang provokasi, fitnah, dan kebohongan-kebohongan besar lainnya. Kata hoaks seringkali kita dengar belakangan ini, terlebih saat perhelatan pemilu mendekati hari-H.

Media sosial merupakan salah satu fenomena yang muncul seiring berkembangnya teknologi dan komunikasi di internet. Sebagai media baru untuk berinteraksi dan bersosialisasi, media sosial juga memiliki pengaruh yang luar biasa terhadap berbagai aspek seperti jurnalisme, public relations dan pemasaran. ${ }^{7}$ Tak dapat dipungkiri bahwa sekarang ini dengan kemajuan teknologi maka peranan media sosial begitu penting dan pesat dalam rangka memberi informasi kepada masyarakat. Pada tanggal 21 April 2008 ditandai dengan diundangkannya Undang-Undang Nomor 11 Tahun 2008 tentang Informasi dan Transaksi Elektronik (Lembaran Negara Republik Indonesia Tahun 2008 Nomor 58, Tambahan Lembaran Negara Republik Indonesia Nomor 4843, untuk selanjutnya disingkat UU ITE). UU ITE ini kemudian diubah dengan Undang-Undang Nomor 19 Tahun 2016 Tentang Perubahan Undang-Undang Nomor 11 Tahun 2008 Tentang Informasi dan Transaksi Elektronik (Lembaran Negara Republik Indonesia Tahun 2016 Nomor 251, Tambahan Lembaran Negara Republik Indonesia Nomor 5952. Disebutkan dalam Penjelasan Umum UU ITE, bahwa:

“Teknologi Informasi saat ini menjadi pedang bermata dua, oleh karena selain memberikan kontribusi bagi peningkatan kesejahteraan, kemajuan dan peradaban manusia, sekaligus menjadi sarana efektif perbuatan melawan hukum". Lebih lanjut disebutkan sekarang ini telah lahir rezim hukum baru yang dikenal dengan hukum siber atau hukum telematika, hukum teknologi informasi (law of Information technology), hukum dunia maya (virtual word law), hukum mayantara. Istilah yang dikenal untuk tindak pidana di bidang ITE adalah Cybercrime. ${ }^{8}$

\footnotetext{
${ }^{7}$ Rulli Nasrullah, Media Sosial Perspektif Komunikasi, Budaya dan Sosioteknologi, Simbiosa Rekatama Media, Bandung, 2017, h. 232

8 Didik Endro Purwoleksono, Pengantar buku Pidana Pemberitaan Media Sosial (Kebebasan Pers, Kode Etik Jurnalistik dan Pertanggungjawaban Pidana) karya Nynda Fatmawati Octarina, Setara Pers, 2018. h. xv.
} 
Adalah berita bohong (hoaks) Ratna Sarumpaet yang membuat peneliti ${ }^{9}$ ingin mengupas lebih jauh mengenai hoaks, media sosial dan pengaturan perundangundangan di dalamnya. Ratna mengaku dipukuli orang tak dikenal di Bandara Husein Sastranegara, Bandung. Kasusnya heboh, viral dan membuat pasangan salah satu capres melakukan konferensi pers. Polisi bergerak cepat hingga akhirnya ketahuan. Ratna yang aktivis dan pernah menjadi artis di era 80- an itu diketahui berbohong. Lebam pada wajahnya bukan dikarenakan dipukuli orang, melainkan bekas operasi plastik. Beruntung gerak cepat polisi membuka kedok Ratna yang sesungguhnya. Dia telah berbohong dikeroyok orang tak dikenal, padahal lebam di wajahnya gara-gara operasi plastik di RS Bina Medika Menteng, Jakarta.

Publik mengira Ratna akan didakwa Undang-undang No 19 Tahun 2016 Tentang Perubahan Undang-Undang Nomor 11 Tahun 2008 Tentang Informasi dan Transaksi Elektronik (Lembaran Negara Republik Indonesia Tahun 2016 Nomor 251, Tambahan Lembaran Negara Republik Indonesia Nomor 5952). Pasal 28 ayat (2) jo Pasal 45 ayat (2). Ternyata Ratna juga didakwa dengan Undang- Undang Nomor 1 Tahun 1946 Tentang Peraturan Hukum Pidana (Lembaran Negara Republik Indonesia Tahun 1958 Nomor 127). Pasal 14 ayat (1).

Pada 11 Juli 2019 Ratna Sarumpaet dinyatakan bersalah dan diganjar hukuman penjara 2 tahun. Vonis ini lebih ringan dari tuntutan jaksa 6 tahun penjara. Kabar terakhir Ratna mengajukan banding sehubungan dengan kalimat hakim di akhir persidangan bahwa kasusnya telah menimbulkan benih-benih keonaran. Hingga tesis ini dibuat kasus Ratna Sarumpaet masih terus berproses di lembaga peradilan.

Hal lainnya yang menjadi ketertarikan penulis untuk meneliti hal ini adalah tentang media cetak mainstream (koran) yang sangat ketat dalam menerbitkan suatu berita justru terkena hoaks. Seperti potongan berita yang diproduksi sedemikian rumah

\footnotetext{
${ }^{9}$ Anny Susilowati, mahasiswa Program Studi Hukum Program Magister Ilmu Hukum Universitas Borneo Tarakan Angkatan 2017.
} 
seolah-olah merupakan produk koran yang bersangkutan. Padahal bukan. Justru menyesatkan pembaca dan menimbulkan kerugian bagi perusahaan media.

B. Rumusan Masalah

Terkait paparan di atas maka penulis merumuskan setidaknya dua permasalahan utama yang akan dibahas kali ini, yaitu:

1. Kriteria berita bohong (hoaks) pada media social

C. Tujuan

1. Untuk menganalisis dan menjelaskan tentang sejumlahperaturan perundang-undangan yang berkaitan dengan berita bohong (hoaks).

2. Untuk menganalisis dan menjelaskan tentang kriteria berita bohong (hoaks) yang terdapat pada media sosial.

\section{Konsep Berita Bohong (Hoaks)}

Istilah hoax atau hoaks adalah usaha untuk menipu atau mengakali pembaca atau pendengarnya untuk mempercayai sesuatu, padahal sang pencipta berita palsu tersebut tahu bahwa berita tersebut adalah palsu. ${ }^{10}$ Salah satu contoh pemberitaan palsu yang paling umum adalah mengklaim sesuatu barang atau kejadian dengan suatu sebutan yang berbeda dengan barang/kejadian sejatinya. Suatu pemberitaan palsu berbeda dengan misalnya pertunjukan sulap; dalam pemberitaan palsu, pendengar/penonton tidak sadar sedang dibohongi, sedangkan pada suatu pertunjukan sulap, penonton justru mengharapkan supaya ditipu. $^{11}$

Hoaks dengan "ks" di belakang sebagai bentuk kata serapan dari bahasa

\footnotetext{
${ }^{10}$ Abner, Khaidir dkk, Penyalahgunaan Informasi Berita Hoax di Media Sosial, https://mti.binus.ac.id/2017/07/03/penyalahgunaan-informasiberita-hoax-di-mediasosial/Diunduh tanggal 2 November 2018. Jurnal

11 https://id.wikipedia.org/wiki/berita_bohong
} 
asing hoax yang belakangan kerap ramai digunakan, terutama di ranah media sosial. Kata atau lema --istilah kata atau frasa masukan dalam kamus-- tersebut kini sudah terdaftar di dalam Kamus Besar Bahasa Indonesia atau KBBI edisi V yang juga tersedia secara online atau dalam jaringan (daring). Selain kata hoaks, kata meme juga masuk peluncuran (KBBI V online) karena setelah peluncuran itu ada pemutakhiran (penambahan lema) sampai bulan April. Adapun kata hoaks dalam KBBI dikategorikan sebagai ajektiva dan nomina. Sebagai ajektiva, kata hoaks berarti tidak benar; bohong. Dalam penulisannya sebagai frasa, hoaks ini menggunakan kata yang diterangkan terlebih dahulu, misalnya menjadi "berita hoaks". Namun, hoaks juga bisa berdiri sendiri sebagai nomina dengan arti "berita bohong".

Bagaimana Hoaks Bekerja? Ada dua faktor yang dapat menyebabkan seseorang cenderung mudah percaya pada hoaks. Orang lebih cenderung percaya hoaks jika informasinya sesuai dengan opini atau sikap yang dimiliki (Respati, 2017). Contohnya jika seseorang penganut paham bumi datar memperoleh artikel yang membahas tentang berbagai teori konspirasi mengenai foto satelit maka secara naluri orang tersebut akan mudah percaya karena mendukung teori bumi datar yang diyakininya. Secara alami perasaan positif akan timbul dalam diri seseorang jika opini atau keyakinannya mendapat afirmasi sehingga cenderung tidak akan mempedulikan apakah informasi yang diterimanya benar dan bahkan mudah saja bagi mereka untuk menyebarkan kembali informasi tersebut. Hal ini dapat diperparah jika si penyebar hoaks memiliki pengetahuan yang kurang dalam memanfaatkan internet guna mencari informasi lebih dalam atau sekadar untuk cek dan ricek fakta.

Terdapat empat mode dalam kegiatan penemuan informasi melalui internet, diantaranya adalah:

\section{a. Undirected viewing}

Pada undirected viewing, seseorang mencari informasi tanpa tahu informasi tertentu dalam pikirannya. Tujuan keseluruhan adalah untuk mencari informasi secara luas dan sebanyak mungkin dari beragam sumber 
informasi yang digunakan dan informasi yang didapatkan kemudian disaring sesuai dengan keinginannya.

b. Pada conditioned viewing, seseorang sudah mengetahui akan apa yang dicari, sudah mengetahui topik informasi yang jelas, Pencarian informasinya sudah mulai terarah.

c. Mode informal search, seseorang telah mempunyai pengetahuan tentang topik yang akan dicari. Sehingga pencarian informasi melalui internet hanya untuk menambah pengetahuan dan pemahaman tentang topik tersebut. Dalam tipe ini pencari informasi sudah mengetahui batasanbatasan sejauh mana seseorang tersebut akan melakukan penelusuran. Namun dalam penelusuran ini, seseorang membatasi pada usaha dan waktu yang ia gunakan karena pada dasarnya, penelusuran yang dilakukan hanya bertujuan untuk menentukan adanya tindakan atau respons terhadap kebutuhannya.

d. Pada formal search, seseorang mempersiapkan waktu dan usaha untuk menelusuri informasi atau topik tertentu secara khusus sesuai dengan kebutuhannya. Penelusuran ini bersifat formal karena dilakukan dengan menggunakan metode- metode tertentu. Tujuan penelusuran adalah untuk memperoleh informasi secara detail guna memperoleh solusi atau keputusan dari sebuah permasalahan yang dihadapi (Choo, Detlor, \& Turnbull, 1999).

Perilaku penyebaran hoaks melalui internet sangat dipengaruhi oleh pembuat berita baik itu individu maupun berkelompok, dari yang berpendidikan rendah sampai yang tinggi dan terstruktur rapi. (Lazonder, Biemans, \& Wopereis, 2000) menunjukkan bahwa terdapat perbedaan antara seseorang yang memiliki keahlian khusus dalam menggunakan mesin pencari (search engine) dengan orang yang masih baru atau awam dalam menggunakan search engine. Mereka dibedakan oleh pengalaman yang dimiliki. Individu yang memiliki pengalaman lebih banyak dalam memanfaatkan search engine, akan cenderung lebih sistematis dalam melakukan penelusuran dibandingkan dengan yang masih minim pengalaman. 
Kata hoax sendiri muncul pertama kali dari sebuah film yang berjudul The Hoax. The Hoax adalah sebuah film drama Amerika 2006 yang disutradarai oleh Lasse Hallstrom yang diskenario oleh William Wheeler. Film ini

dibuat berdasarkan buku dengan judul yang sama oleh Clifford Irving dan berfokus pada biografi Irving sendiri, serta Howard Hughes yang dianggap membantu Clifford Irving. Banyak kejadian yang diuraikan Irving dalam bukunya yang diubah atau dihilangkan dari film.

\section{Konsep Media Sosial}

Media sosial merupakan salah satu platform yang muncul di media cyber atau siber. Karena itu, melihat media sosial yang ada tidak jauh berbeda dengan karakteristik yang dimiliki media siber. ${ }^{12}$ Meskipun karakteristik media siber bisa dilihat melalui media sosial, tetapi media sosial memiliki karakteristik khusus yang tidak dimiliki media siber lainnya. Ada batasan-batasan dan ciri khusus yang hanya dimiliki oleh media sosial dibanding dengan media lainnya. Salah satunya adalah media sosial beranjak dari pemahaman bagaimana media tersebut digunakan sebagai sarana sosial di dunia virtual. Bukan berarti tak ada karakter umum atau makro, hanya pembahasan karakteristik media sosial ini dipandang perlu untuk melihat pembedaan dengan media lainnya.

Pada akhirnya, bagaimana karakteristik media sosial itu bisa dipergunakan untuk bidang seperti jurnalisme, hubungan masyarakat, pemasaran dan politik. Adapun karakteristik media sosial adalah sebagai berikut:

\section{a. Jaringan (Networking)}

Kata jaringan bisa dipahami dalam terminologi bidang teknologi seperti ilmu komputer. Namun kata ini berkembang dari sekadar istilah yang digunakan dalam ilmu komputer menjadi istilah yang akrab digunakan dalam kajian budaya dan sosial.

12 Rulli Nasrullah, Media Sosial Perspektif Komunikasi, Budaya dan Sosioteknologi, Simbiosa Rekatama Media, 2017. h. 16. 
b. Informasi (Information)

Informasi menjadi entitas yang penting dari media sosial. Sebab tidak seperti media-media lainnya di internet, pengguna media sosial mengkreasikan representasi identitasnya, memproduksi konten dan melakukan interaksi berdasarkan informasi.

c. Arsip (Archive)

Bagi pengguna media sosial, arsip menjadi sebuah karakter yang menjelaskan bahwa informasi telah tersimpan dan bisa diakses kapan pun dan melalui perangkat apapun. Misalnya arsip di facebook. Kapan saja akses informasi yang pernah diunggah, seketika itu pula bisa dimunculkan.

d. Interaksi (Interactivity)

Karakter dasar dari media sosial adalah terbentuknya jaringan antarpengguna. Jaringan ini tidak sekadar memperluas hubungan pertemanan atau pengikut atau follower di internet semata, tetapi juga harus dibangun dengan interaksi antarpengguna tersebut.

e. Simulasi sosial (Simulation of society)

Media sosial memiliki karakter sebagai medium berlangsungnya masyarakat (society) di dunia virtual. Media sosial memiliki keunikan dan pola yang dalam banyak kasus berbeda dan tidak dijumpai dalam tatanan masyarakat yang real

f. Konten oleh pengguna (user-generated content)

Konten oleh pengguna atau lebih popular disebut dengan user generated content. Term ini menunjukkan bahwa di media sosial konten sepenuhnya milik dan berdasarkan kontribusi pengguna atau pemilik akun.

g. Penyebaran (share atau sharing)Medium ini tidak hanya menghasilkan konten yang dibangun dari dan dikonsumsi oleh penggunanya tetapi juga didistribusikan dan sekaligus dikembangkan oleh penggunanya.

Konsep e-Commerce

Konsep perdagangan dengan menggunakan media internet lebih dikenal dengan electronic commerce (e-commerce). e-commerce lahir selain karena adanya perkembangan teknologi juga karena adanya permintaan masyarakat yang 
menginginkan pelayanan serba cepat, mudah dan praktis ${ }^{13}$

Adapun e-commerce tersebut terbagi atas dua segmen, pertama yaitu, business to business e-commerce (perdagangan antar pelaku usaha) atau yang lebih dikenal business to business B2B. Kedua, business to consumer (perdagangan antar pelaku usaha dengan konsumen) atau lebih dikenal sebagai business to consumer B2C. Sistem perdagangan dengan memanfaatkan internet inilah yang mengubah wajah bisnis di Indonesia. Richard Rosecrance memaparkan betapa besar kekuatan yang dapat diwujudkan suatu bangsa melalui kemampuan dagangnya. Kegiatan perdagangan mampu mengganti ekspansi wilayah dan perang militer sebagai kunci pokok menuju kesejahteraan dan pencapaian kekuatan internasional, disimpulkannya bahwa manfaat perdagangan dan kerjasama perdagangan internasional dewasa ini jauh melampaui manfaat persaingan militer dan perluasan wilayah.

Sebagai suatu perdagangan yang berbasis teknologi canggih, transaksi bisnis yang menggunakan $e$-commerce telah mereformasi perdagangan konvensional, dimana interaksi antara para pihak yang sebelumnya dilakukan secara langsung menjadi interaksi yang tidak langsung, e-commerce telah merubah paradigma bisnis klasik dengan menumbuhkan model-model interaksi antara para pihak di dunia virtual.

Selain dua segmen diatas, terdapat pula tambahan satu segmen lagi yaitu, Consumen to Business (C2B). Ciri-cirinya adalah adanya suatu kebutuhan atas permintaan khusus dari konsumen ke produsen serta jenis bisnis ini didominasi oleh bisnis dalam bidang jasa. ${ }^{14}$

\section{A. Metode Penelitian}

Metode penelitian yang digunakan dalam penelitian ini secara keseluruhan adalah sebagai berikut:

${ }^{13}$ Rulli Nasrullah, Media Sosial Perspektif Komunikasi, Budaya dan Sosioteknologi, Simbiosa Rekatama Media, 2017. h. 16.

${ }^{14}$ Rahmat Makmur, Manajemen E-commerce, Informatika, Bandung, 2018. 
1. Tipe Penelitian

Jenis penelitian ini adalah jenis penelitian normatif, yaitu dengan cara mengkaji peraturan perundang-undangan yang berhubungan denganpermasalahan yang diangkat dan akan dianalisis oleh penulis berkaitan dengan berita bohong (hoaks) pada media sosial dalam perspektif perundang-undangan di Indonesia.

\section{Pendekatan Masalah}

Dalam penelitian hukum menurut Peter Mahmud Marzuki terdapat beberapa pendekatan masalah. Dengan adanya pendekatan tersebut peneliti akan mendapatkan informasi dari berbagai aspek mengenai isu yang sedang dicoba dicari jawabannya. Pendekatan-pendekatan yang digunakan dalam penelitian ilmu hukum adalah pendekatan undangundang (statute approach), pendekatan kasus (case approach), pendekatan historis (historical approach), pendekatan komparatif (comparative approach), dan pendekatan konseptual (conceptual approach).

a. Pendekatan Undang-undang (statute approach)

Pendekatan undang-undang dilakukan dengan menelaah semua undang-undang dan regulasi yang berkaitan dengan isu hukum yang sedang ditangani.

b. Pendekatan Kasus (Case Approach)

Pendekatan kasus dilakukan dengan cara melakukan telaah terhadap kasus-kasus yang berkaitan dengan isu yang dihadapi yang telah menjadi keputusan pengadilan yang telah memiliki kekuatan tetap.

c. Pendekatan History (Historical Approach)

Pendekatan historis dilakukan dengan menelaah latar belakang apa yang dipelajari dan berkembang pengaturan mengenai isu yang dihadapi. 


\section{d. Pendekatan Komparatif (Comparative Approach)}

Pendekatan komparatif adalah pendekatan dengan membandingkan undang-undang suatau negara dengan undang-undang dari satu atau lebih negara lain mengenai hal yang sama.

e. Pendekatan Konseptual (Conceptual Approach)

Pendekatan konseptual adalah pendekatan yang beranjak dari pandangan-pandangan dan doktrin-doktrin yang berkembang di dalam ilmu hukum. Dengan mempelajari pandangan-pandangan dan doktrindoktrin dalam ilmu hukum peneliti akan menemukan ide-ide yang melahirkan pengertian-pengertian hukum, konsep-konsep hukum dan azas hukum yang relevan dengan isu yang dihadapi.

Dalam penelitian ini, peneliti menggunakan pendekatan berupa, pendekatan peraturan perundang-undangan (statute approach), pendekatan konseptual (conceptual approach).

\section{a. Sumber Bahan Hukum}

Sumber bahan hukum yang digunakan dalam penelitian ini terdiri dari dua bagian yaitu hukum primer dan hukum sekunder. Bahan Hukum Primer merupakan bahan hukum yang bersifat aurotatif, terdiri dari perundang-undangan, catatancatatan resmi atau risalah dalam pembuatan peraturan perundang-undangan dan putusan hakim.

Dalam penelitian ini bahan hukum primer yang digunakan adalah :

1. Undang-Undang Nomor 12 Tahun 2011 Tentang Pembentukan Peraturan Perundang-undangan Menggantikan Undang-Undang Nomor 10 Tahun 2004 Tentang Pembentukan Peraturan Perundang-undangan. (Lembaran Negara Republik Indonesia Tahun 2011 Nomor 82, Tambahan Lembaran Negara Republik Indonesia Nomor 5234) 
2. Undang-Undang Nomor 19 Tahun 2016 Tentang Perubahan UndangUndang Nomor 11 Tahun 2008 Tentang Informasi dan Transaksi Elektronik. (Lembaran Negara Republik Indonesia Tahun 2016 Nomor 251, Tambahan Lembaran Negara Republik Indonesia Nomor 5952)

3. Undang-Undang Nomor 1 Tahun 1946 Tentang Peraturan Hukum Pidana (Lembaran Negara Republik Indonesia Tahun 1958 Nomor 127)

4. Undang-Undang Nomor 40 Tahun 2008 Tentang Penghapusan Diskriminasi Ras dan Etnis. (Lembaran Negara Republik Indonesia Tahun 2008 Nomor 170, tambahan Lembaran Negara Republik Indonesia Nomor 4919).

5. Undang-undang Nomor 5 Tahun 2018 Tentang Pemberantasan Terorisme. (Lembaran Negara Republik Indonesia Tahun 2018 Nomor 92, Tambahan Lembaran Negara Republik Indonesia Nomor 6216)

6. Undang-Undang Nomor 12 Tahun 2006 Tentang Kewarganegaraan Republik Indonesia (Lembaran Negara Republik Indonesia Tahun 2006 Nomor 63, Tambahan Lembaran Negara Republik Indonesia Nomor 4634)

7. Undang-Undang Nomor 16 Tahun 2000 Tentang Perubahan Kedua Atas Undang-Undang Nomor 6 Tahun 1983 Tentang Ketentuan Umum dan Tatacara Perpajakan. (Lembaran Negara Republik Indonesia Tahun 2000 Nomor 126, Tambahan Lembaran Negara Republik Indonesia Nomor 3984)

8. Undang-Undang Nomor 21 Tahun 2007 Tentang Pemberantasan Tindak Pidana Perdagangan Orang. (Lembaran Negara Republik IndonesiaTahun2007 Nomor 58, Tambahan Lembaran Negara Republik Indonesia Nomor 4720)

9. Undang-Undang Nomor 12 Tahun 2008 Tentang Perubahan Kedua Atas Undang-Undang Nomor 32 Tahun 2004 Tentang Pemerintahan Daerah. (Lembaran Negara Republik Indonesia Tahun 2008 Nomor 59, Tambahan Lembaran Negara Republik Indonesia Nomor 4844)

10. Undang-Undang Nomor 15 Tahun 2012 Tentang Veteran Republik Indonesia. (Lembaran Negara Republik Indonesia Tahun 2012 Nomor 182, Tambahan Lembaran Negara Republik Indonesia Nomor 5342) 
11. Undang-Undang Nomor 17 Tahun 2006 Tentang Perubahan UndangUndang Nomor 10 tahun 1995 Tentang Kepabeanan. (Lembaran Negara Republik Indonesia Tahun 2006 Nomor 93, Tambahan Lembaran Negara Republik Indonesia Nomor 4661)

12. Undang-Undang Nomor 16 tahun 2009 Tentang Penetapan Peraturan Pemerintah Pengganti Undang-undang Nomor 5 Tahun 2008, Tentang Perubahan Keempat atas Undang-undang Nomor 6 Tahun 1983, Tentang Ketentuan Umum dan Tata Cara Perpajakan Menjadi Undang-undang. (Lembaran Negara Republik Indonesia Tahun 2009 Nomor 62, Tambahan Lembaran Negara Republik Indonesia Nomor 4999).

13. Undang-Undang Nomor 32 Tahun 2009 Tentang Perlindungan dan Pengelolaan Lingkungan Hidup. (Lembaran Negara Republik Indonesia Tahun 2009 Nomor 140, Tambahan Lembaran Negara Republik Indonesia Nomor 5059)

14. Undang-Undang Nomor 6 Tahun 2011 Tentang Keimigrasian. (Lembaran Negara Republik Indonesia Tahun 2011 Nomor 52, Tambahan Lembaran Negara Republik Indonesia Nomor 5216)

15. Undang-Undang Nomor 8 Tahun 1995 Tentang Pasar Modal. (Lembaran Negara Republik Indonesia Tahun 1995 Nomor 64, Tambahan Lembaran Negara Republik Indonesia 3608)

16. Undang-Undang Nomor 8 Tahun 2012 Tentang Pemilihan Umum Anggota Dewan Perwakilan Rakyat, Dewan Perwakilan Daerah, dan

Dewan Perwakilan Rakyat Daerah. (Lembaran Negara Republik Indonesia Tahun 2012 Nomor 117, Tambahan Lembaran Negara Republik Indonesia Nomor 5316)

17. PP RI No. 82 Tahun 2012 Tentang Penyelenggaraan Sistem dan Transaksi Elektronik. (Lembaran Negara Republik Indonesia Tahun 2012 Nomor 189, Tambahan Lembaran Negara Republik Indonesia Nomor 5348)

18. Permenkominfo RI No.7 Tahun 2016 Tentang Administrasi Penyidikan dan Penindakan Tindak Pidana di Bidang Teknologi Informasi dan Transaksi Elektronik. (Berita Negara Republik Indonesia Tahun 2016 Nomor 709) 
19. Surat Edaran (SE) Nomor SE/6/X/2015 tentang Penanganan Ujaran Kebencian yang dikeluarkan Kepolisian Republik Indonesia.

Selain bahan hukum primer, penelitian ini juga menggunakan bahan hukum sekunder, yakni bahan hukum yang memberikan penjelasan terhadap bahan hukum primer yang menjadi rujukan, yang didapatkan dari buku-buku hukum termasuk tesis dan disertasi hukum, jurnal-jurnal hukum, kamus-kamus hukum dan komentar-komentar serta hasil penelitian sebelumnya yang terkait dengan permasalahan yang mendukung penelitian ini.

a. Teknik Pengumpulan Bahan Hukum

Semua bahan hukum yang hendak dijadikan sebagai instrumen analisis, akan dikumpulkan dan dikualifikasi oleh peneliti dengan menggunakan metode bola salju (snow ball theory) , kemudian diinventarisasi dan diidentifikasi, yang untuk selanjutnya digunakan dalam menganalisis permasalahan yang berhubungan dengan penelitian ini. Untuk kepentingan inventarisasi serta identifikasi bahan hukum, maka digunakan sistem kartu (card system) yang penatalaksanaannya dilakukan dengan secara kritis, logis dan sistematis.

\section{b. Analisa Bahan Hukum.}

Pada penelitian hukum normatif pengolahan data dilakukan dengan cara melakukan sistematika terhadap bahan-bahan hukum tertulis. Sistematisasi berarti membuat klasifikasi terhadap bahan-bahan hukum tersebut untuk memudahkan pekerjaan analisis dan konstruksi. Kegiatan yang dilakukan dalam analisis data penelitian hukum normatif dengan cara data yang diperoleh dianalisis secara deskriptif kualitatif, yaitu analisa data yang tidak dapat dihitung. Bahan-bahan hukum yang telah dikumpulkan dan diklasifikasi selanjutnya dilakukan analisis untuk menginterpretasi hukum yang berlaku dengan cara menguraikan isi dari bahan hukum primer maupun bahan hukum sekunder. Analisis bahan hukum menyangkut kegiatan penalaran ilmiah terhadap bahanbahan hukum yang dianalisis, baik menggunakan penalaran induksi dan deduksi. 
Jenis analisis yang dapat digunakan untuk menganalisa bahan-bahan hukum adalah analisa kualitatif. Dalam penelitian ini jenis analisis yang digunakan adalah analisis bahan hukum yang sifatnya kualitatif karena sesuai dengan tujuan dan tipe penelitian.

Analisis bahan-bahan hukum bertujuan untuk mendapatkan aturan-aturan hukum atau pendapat dari para ahli yang dipergunakan sebagai pemecahan permasalahan dan dirumuskan sebagai suatu kesimpulan. Kesimpulan yang telah dirumuskan sebagai intisari dari rumusan masalah atau isu hukum yang diteliti diharapkan dapat digunakan untuk pengembangan dan penerapan ilmu hukum.

\section{KRITERIA BERITA BOHONG (HOAKS) PADA MEDIA SOSIAL}

Berita bohong atau hoax yang diindonesiakan menjadi hoaks telah mewabah hampir di seluruh pelosok negeri. Keberadaannya telah menjadi masalah nasional hingga mengancam timbulnya perpecahan, instabilitas politik dan gangguan keamanan yang berpotensi menghambat pembangunan nasional. Dalam situasi seperti ini berita baik pun dikira berita bohong. Hal ini membuat masyarakat kebingungan dan sulit membedakan mana berita yang mengandung kebenaran dan mana berita bohong yang sesungguhnya.

Ditengah situasi carut marut seperti itu, Presiden Republik Indonesia Joko Widodo memerintahkan jajarannya dan seluruh elemen masyarakat untuk segera menghentikan penyebaran berita bohong dan fitnah. Hal itu diketahui dari artikel yang dimuat detik.com tanggal 9 Februari 2017 berjudul "Hentikan Penyebaran Berita Bohong dan Fitnah".15 Pun di kesempatan berikutnya presiden menegaskan kembali bahwa, "Pemerintah Terus Perangi Hoax" seperti dimuat beritasatu.com, 22 Januari 2017.16

\footnotetext{
15 https://www.detik.com/hentikan-penyebaran-berita-bohong-dan-fitnah. Diterbitkan tanggal 9 Februari 2017

${ }^{16}$ https://www.beritasatu.com/pemerintah-terus-perangi-hoax. Diterbitkan tanggal 22
} 
Sementara itu sejumlah pejabat serentak angkat bicara untuk mendukung apa yang disampaikan presiden, Menko Polhukam Jenderal Wiranto mengungkapkan,"Berita Hoax Merugikan Masyarakat dan Mengganggu

Pembangunan Nasional," seperti dikutip media antaranews.com pada 3 Januari 2017.17 Jenderal Gatot Nurmantyo yang saat itu masih menjabat Panglima TNI pun mengkhawatirkan adanya perpecahan gara-gara berita bohong. "Berita Hoax Bisa Timbulkan Perpecahan," ujarnya, seperti dimuat dalam situs beritasatu.com tanggal 22 Januari 2017.18

Kapolri Jenderal Tito Karnavian justru mengingatkan bahayanya media sosial yang saat ini banyak digandrungi. Sebab selain sebagai alat komunikasi efektif yang mendekatkan jarak dan waktu, ternyata media sosial juga rentan terhadap penyebaran hoaks. "Terlalu Banyak Informasi Hoax di Media Sosial," kata Tito, seperti dilansir tribunnews.com, tanggal 5 November 2016. ${ }^{19}$ Pencerahan justru datang dari Menkominfo Rudiantara. Menurutnya,"Media Cetak Menjadi Alternatif Melawan Hoax." Seperti dikutip dari berita Sindonews.com tanggal 4 Februari 2017.20

Menurut penulis, para petinggi negara sudah memperingatkan adanya bahaya berita bohong (hoaks) berdasarkan kasus-kasus yang mereka alami di

Januari 2017.

${ }^{17}$ https://www.antaranews.com/berita-hoax-merugikan-masyarakat-dan-mengganggu pembangunan-nasional. Diterbitkan pada tanggal 3 Januari 2017

${ }^{18}$ https://www.beritasatu.com/berita-hoax-bisa-timbulkan-perpecahan. Diterbitkan tanggal 22 Januari 2017

1931 https://www.tribunnews.com/terlalu-banyak-informasi-hoax-di-media-sosial/.

Diterbitkan tanggal 5 November 2016

${ }^{20}$ https://www.sindonews.com/media-cetak-menjadi-alternatif-melawan-hoax. 
lapangan dalam bertugas. Tetapi yang menarik adalah pernyataan Menkominfo Rudiantara, bahwa media cetak masih mumpuni untuk menjadi alternatif melawan berita hoaks. Mengapa demikian? Karena media cetak menerapkan cek ricek dan

kroscek berita sebelum diterbitkan. Berita harus berimbang. Berita harus mengandung unsur $5 \mathrm{~W}+1 \mathrm{H}$, yaitu What (Apa), Where (Di Mana), When (Kapan), Who (Siapa), Why (Mengapa) + How (Bagaimana) adalah hal-hal yang tidak boleh diabaikan dalam penulisan sebuah berita. Selain $5 \mathrm{~W}+1 \mathrm{H}$, penulis juga menambahkan unsur Safety atau keamanan dalam sebuah berita. Sehingga rumusnya menjadi $5 \mathrm{~W}+1 \mathrm{H}+1 \mathrm{~S}$.

Teknologi komputer baik perangkat keras (hardware) dan perangkat lunak (software), jaringan komunikasi dan teknologi multimedia menjadi tulang punggung masyarakat abad 21. Namun demikian, selain keuntungan yang menjanjikan dari teknologi informasi, teknologi internet ternyata memunculkan permasalahan baru dalam tatanan kehidupan bermasyarakat, misalnya pelanggaran hak kekayaan intelektual; penipuan dalam transaksi elektronik; perpajakan dalam perdagangan elektronik; dan cybercrime. ${ }^{21}$

Seiring dengan perkembangan dunia informasi, memberikan kita berbagai kemudahan untuk dengan cepat mendapatkan berbagai kabar berita terbaru dari seluruh dunia. Tak hanya untuk mendapatkan berbagai informasi atau berita, dunia internet dan media sosial juga dapat kita gunakan untuk berbagi informasi dan menyebarluaskan berbagai berita keseluruh dunia dengan sangat cepat. ${ }^{22}$ Bahkan berita bohong (hoaks) atau informasi palsu pun yang tersebar dengan sangat cepat di dunia internet dan sosial media tersebut berisikan tentang hal-hal besar yang menggemparkan dunia, berisi tentang

${ }^{21}$ Danrivanto Budhijanto, Revolusi Cyberlaw Indonesia Pembaruan dan Revisi UU ITE 2016, Refika Aditama, Bandung, 2017, h. 3

${ }^{22}$ Nudirman Munir, Pengantar hukum siber Indonesia, Raja Grafindo Persada, Depok, 2019, h.258 
provokasi, fitnah, dan kebohongan-kebohongan besar lainnya. Kata hoaks seringkali kita dengar belakangan ini, terlebih menjelang perhelatan pemilu.

Kesimpulan

Kasus berita bohong (hoaks) adalah delik aduan. Artinya baru bisa diproses hukum setelah ada yang melaporkan ke aparat kepolisian. Kasus ini tidak berdiri sendiri dan dalam roses itupun kasus-kasus hoaks harus memenuhi unsur-unsur berita bohong.

Saran

Mengingat perkembangan media sosial yang sangat pesat, penulis menyarankan perlunya undang-undang khusus media sosial yang terlepas dari UU ITE. Undangundang ini secara spesifik mengatur persoalan media sosial dari hulu ke hilir dibahas semua. Tujuannya mengatur lalu lintas media sosial ke arah yang lebih positif dalam mewujudkan internet sehat. Kemudian menjadi panduan agar netizen atau warganet tertib dan bijak dalam menggunakan media sosial. Sehingga dapat mengurangi dampak dari berita bohong (hoaks).

Pada 2030 Indonesia akan mengalami bonus demografi dimana anak muda saat itu dalam usia keemasannya. Bila UU Media Sosial bisa segera diterapkan bukan tidak mungkin akan menghasilkan generasi emas yang tidak saja mengerti bagaimana harus menyikapi media sosial, tetapi juga memanfaatkan media sosial untuk tujuan yang mulia.

\section{DAFTAR BACAAN}

\section{A. Buku}

Bambang Rudito dan Melia Famiola, Social Mapping, Penerbit Rekayasa Sains Bandung, 2008.

Danrivanto Budhijanto, Revolusi Cyberlaw Indonesia Pembaharuan dan Revisi UU ITE 2016, Penerbit PT Refika Aditama, 2017. 
Dinar Apriyanto, Passion For Millenial People, Penerbit PT Anak Hebat Indonesia, 2017.

Didik Endro Purwoleksono, Hukum Pidana Untaian Pemikiran, Penerbit Airlangga University Press, Surabaya, 2019.

Dewan Pers, Buku Saku Wartawan, Penerbit Sekretariat Dewan Pers Jakarta, Cetakan Kesembilan, Maret 2019.

Haris Sumadiria, Hukum dan Etika Media Massa Panduan Pers, Penyiaran, dan Media Siber, Penerbit Simbiosa Rekatama Media, 2016.

Ishaq, Metode Penelitian Hukum, Penerbit Alfabeta Bandung, 2017.

Irman Syahrial, Hukum Pers (Telaah Teoritis atas Kepastian Hukum dan Kemerdekaan Pers di Indonesia). Penerbit Laksbang Pressindo, Yogyakarta, 2015.

Kovak, Bill dan Tom Rosentiel, The Elements of journalism, what newspeople should know and The Pblic Should Expert. Yusi A Pareanom (penerj.) Elemen-elemen jurnalisme, apa yang seharusnya diketahui wartawan dan diharapkan public, Penerbit ISAI, Jakarta

Madcoms dan Andi Offset, Berinternet dengan Facebook dan Twitter, Penerbit Andi Offset, 2011.

Mukti Fajar dan Yulianto Achmad, Dualisme Penelitian Hukum Normatif dan Empiris, Cetakan keempat 2017.

Nur Syam, Media Sosial Interaksi, Identitas, dan Modal Sosial, Penerbit Prenada Media Group, Cetakan Kedua 2016.

Nudirman Munir, Pengantar Hukum Siber Indonesia, Penerbit Rajagrafindo Persada, 2017.

Nuruddin, Tuhan Baru Masyarakat Cyber di Era Digital, Penerbit Aditya Media Publishing, 2012

Nynda Fatmawati Octarina, Pidana Pemberitaan Media Sosial Kebebasan Pers, kode etik jurnalistik dan pertanggungjawaban pidana, Penerbit Setara Press, Malang, 2018. 
Otje Salman dan Anton F Susanto, Teori Hukum Mengingat Mengumpulkan dan Membuka Kembali, Penerbit Refika Aditama, Cetakan ke-8 Tahun 2015.

Peter Mahmud, Penelitian Hukum, Penerbit Prenada Media Group, Cetakan 12 Tahun 2016.

Peter Mahmud Marzuki, Pengantar Ilmu Hukum (edisi revisi), Penerbit Kencana Prenada Media Group, Cetakan ke-9 Tahun 2016.

Peter Mahmud Marzuki, An Introduction to Indonesian Law, Penerbit Setara Press Intrans Publishing Group, 2012

Redaksi Sinar Grafika, Amandemen Undang-Undang ITE Informasi dan Transaksi Elektronik (UU RI No. 19 Tahun 2016), Penerbit Sinar Grafika. 2017.

Rulli Nasrullah, Media Sosial Perspektif Komunikasi, Budaya dan Sosioteknologi, Penerbit Simbiosa Rekatama Media, 2017.

Rulli Nasrullah, Teori dan Riset Media Siber (Cybermedia), Penerbit Prenada Media Group, Cetakan Kedua 2016.

Rulli Nasrullah, Khalayak Media Identitas, Ideologi, dan Perilaku di Era Digital, Penerbit Simbiosa Rekatama Media, 2018.

Salmanul Faris dan Irwansyah, Closing Setiap Hari dengan Whatsapp, Penerbit Ednovate

Soerjono Soekanto, Pengantar Penelitian Hukum, Penerbit Universitas Indonesia, 2015,

Sulistyowati Irianto dan Shidarta, Metode Penelitian Hukum, Penerbit Yayasan Pustaka Obor Indonesia, 2017.

Salim HS dan Erlies Septiana Nurbani, Penerapan Teori Hukum Pada Penelitian Disertasi dan Tesis (buku Pertama), Penerbit Rajagrafindo Persada, 2014. 
Salim HS dan Erlies Septiana Nurbani, Penerapan Teori Hukum Pada Penelitian Disertasi dan Tesis (Buku Kedua), Penerbit Rajagrafindo Persada, 2014.

Salim HS dan Erlies Septiana Nurbani, Penerapan Teori Hukum Pada Penelitian Disertasi dan Tesis (buku ketiga), Penerbit Rajagrafindo Persada, 2016.

Soerjono Soekanto dan Sri Mamudji, Penelitian Hukum Normatif Suatu Tinjauan Singkat, Penerbit Rajagrafindo Persada, Cetakan ke-17 Tahun 2017.

Zainuddin Ali, Metode Penelitian Hukum, Penerbit Sinar Grafika, Cetakan ke tujuh 2016.

B,. Jurnal

Abner, Khaidir dkk, Penyalahgunaan Informasi Berita Hoax di Media Sosial, https://mti.binus.ac.id/2017/07/03/penyalahgunaan-informasiberita- hoax-di-mediasosial/Diunduh tanggal 2 November 2018.

Vibriza Juliswara, Mengembangkan Model Literasi Media yang Berkebhinnekaan dalam Menganalisis Informasi Berita Palsu (Hoax) di Media Sosial. Jurnal Pemikiran Sosiologi Volume 4 No. 2, Agustus 2017

Totok Suyanto, dkk, Persepsi Mahasiswa Terhadap Kemunculan Berita Bohong di Media Sosial, Jurnal Civics: Media Kajian Kewarganegaraan Vol. 15 No. 1 Tahun 2018 Hal 52 61.

C. Majalah

Majalah Tempo, Wabah Hoax (Berita Muslihat Berhamburan di Jagat Maya Tempo Menelusuri Pola Penyebaran dan Menemukan Mereka yang Diduga Melakukannya, Edisi 4545/2-8 Januari 2017.

D. Peraturan Perundang-undangan 
Undang-Undang Nomor 12 Tahun 2011 Tentang Pembentukan Peraturan Perundangundangan Menggantikan Undang-Undang Nomor 10 Tahun 2004 Tentang Pembentukan Peraturan Perundang-undangan. (Lembaran Negara Republik Indonesia Tahun 2011 Nomor 82, Tambahan Lembaran Negara Republik Indonesia Nomor 5234)

Undang-Undang Nomor 19 Tahun 2016 Tentang Perubahan Undang-Undang Nomor 11 Tahun 2008 Tentang Informasi dan Transaksi Elektronik. (Lembaran Negara Republik Indonesia Tahun 2016 Nomor 251, Tambahan Lembaran Negara Republik Indonesia Nomor 5952)

Undang-Undang Nomor 1 Tahun 1946 Tentang Peraturan Hukum Pidana (Lembaran Negara Republik Indonesia Tahun 1958 Nomor 127)

Undang-Undang Nomor 40 Tahun 2008 Tentang Penghapusan Diskriminasi Ras dan Etnis. (Lembaran Negara Republik Indonesia Tahun 2008 Nomor 170, tambahan Lembaran Negara Republik Indonesia Nomor 4919)

Undang-undang Nomor 5 Tahun 2018 Tentang Pemberantasan Terorisme. (Lembaran Negara Republik Indonesia Tahun 2018 Nomor 92, Tambahan Lembaran Negara Republik Indonesia Nomor 6216)

Undang-Undang Nomor 12 Tahun 2006 Tentang Kewarganegaraan Republik Indonesia (Lembaran Negara Republik Indonesia Tahun 2006 Nomor 63, Tambahan Lembaran Negara Republik Indonesia Nomor 4634)

Undang-Undang Nomor 16 Tahun 2000 Tentang Perubahan Kedua Atas Undang-Undang Nomor 6 Tahun 1983 Tentang Ketentuan Umum dan Tatacara Perpajakan. (Lembaran Negara Republik Indonesia Tahun 2000 Nomor 126, Tambahan Lembaran Negara Republik Indonesia Nomor 3984)

Undang-Undang Nomor 21 Tahun 2007 Tentang Pemberantasan Tindak Pidana Perdagangan Orang. (Lembaran Negara Republik IndonesiaTahun 2007 Nomor 58, Tambahan Lembaran Negara Republik Indonesia Nomor 4720) 
Undang-Undang Nomor 12 Tahun 2008 Tentang Perubahan Kedua Atas Undang-Undang Nomor 32 Tahun 2004 Tentang Pemerintahan Daerah. (Lembaran Negara Republik Indonesia Tahun 2008 Nomor 59, Tambahan Lembaran Negara Republik Indonesia Nomor 4844)

Undang-Undang Nomor 15 Tahun 2012 Tentang Veteran Republik Indonesia. (Lembaran Negara Republik Indonesia Tahun 2012 Nomor 182, Tambahan Lembaran Negara Republik Indonesia Nomor 5342)

Undang-Undang Nomor 17 Tahun 2006 Tentang Perubahan Undang-Undang Nomor 10 tahun 1995 Tentang Kepabeanan. (Lembaran Negara Republik Indonesia Tahun 2006 Nomor 93, Tambahan Lembaran Negara Republik Indonesia Nomor 4661)

Undang-Undang Nomor 16 tahun 2009 Tentang Penetapan Peraturan Pemerintah Pengganti Undang-undang Nomor 5 Tahun 2008 Tentang Perubahan Keempat atas Undang-undang Nomor 6 Tahun 1983 Tentang Ketentuan Umum dan Tata Cara Perpajakan Menjadi Undang-undang. (Lembaran Negara Republik Indonesia Tahun 2009 Nomor 62, Tambahan Lembaran Negara Republik Indonesia Nomor 4999).

Undang-Undang Nomor 32 Tahun 2009 Tentang Perlindungan dan Pengelolaan Lingkungan Hidup. (Lembaran Negara Republik Indonesia Tahun 2009 Nomor 140, Tambahan Lembaran Negara Republik Indonesia Nomor 5059)

Undang-Undang Nomor 6 Tahun 2011 Tentang Keimigrasian. (Lembaran Negara Republik Indonesia Tahun 2011 Nomor 52, Tambahan Lembaran Negara Republik Indonesia Nomor 5216)

Undang-Undang Nomor 8 Tahun 1995 Tentang Pasar Modal. (Lembaran Negara Republik Indonesia Tahun 1995 Nomor 64, Tambahan Lembaran Negara Republik Indonesia 3608)

Undang-Undang Nomor 8 Tahun 2012 Tentang Pemilihan Umum Anggota Dewan Perwakilan Rakyat, Dewan Perwakilan Daerah, dan Dewan

Perwakilan Rakyat Daerah. (Lembaran Negara Republik Indonesia Tahun 2012 Nomor 
117, Tambahan Lembaran Negara Republik Indonesia Nomor 5316)

PP RI No. 82 Tahun 2012 Tentang Penyelenggaraan Sistem dan Transaksi Elektronik. (Lembaran Negara Republik Indonesia Tahun 2012 Nomor 189, Tambahan Lembaran Negara Republik Indonesia Nomor 5348)

Permenkominfo RI No.7 Tahun 2016 Tentang Administrasi Penyidikan dan Penindakan Tindak Pidana di Bidang Teknologi Informasi dan Transaksi Elektronik. (Berita Negara Republik Indonesia Tahun 2016 Nomor 709)

Surat Edaran (SE) Nomor SE/6/X/2015 tentang Penanganan Ujaran Kebencian yang dikeluarkan Kepolisian Republik Indonesia. (Berita Negara Republik Indonesia Nomor

E. Internet

https://www.apjii.or.id/content/read/39/342/Hasil-Survei-Penetrasi-dan-Perilaku Pengguna Internet-Indonesia-2017. Diunduh tanggal 6 april 2019 pukul 10.05 wita. https://databoks.katadata.co.id/datapublish/2019/02/06/ditingkat-asean-penetrasiinternet-di-bawah-vietnam. Diunduh 6 april 2019 pukul 10.10 wita.

Badan Pusat Statistik, Statistik Telekomunikasi Indonesia 2017, katalog 8305002, BPS 2017. https://www.bps.go.id/publication/download.html?

https://www.idntimes.com/tech/gadget/eka-supriyadi/daftar-6-negara-penggunaponsel- terbanyak-di-dunia-ada-indonesia-c1c2/full https;//metro.tempo.co/read/1180886/cerita-jaksa-soal-awal-mula-kebohonganratna-sarumpaet//full?view=ok. Diunduh tanggal 1 Maret 2019 pukul 19.00 wita.

Maria Farida Indrati Suprapto, Ilmu Perundang-undangan Proses dan Teknik Pembentukannya, Yogyakarta, Kanisius, 2007. 
